\title{
Licenciatura en nutrición de la Universidad Nacional del Litoral: la mirada de sus graduados recientes
}

\author{
Paulini, Rosario B. ${ }^{1}$; Dezar, Gimena V. ${ }^{2}$
}

Recibido: 22/09/2016

Aprobado: 05/12/2016

\section{Resumen}

El presente trabajo se sustenta en el reconocimiento de que los estudios de seguimiento de egresados constituyen una estrategia de investigación evaluativa de las instituciones de educación superior, en tanto permiten indagar sobre el impacto de la formación en los procesos de inserción, desarrollo profesional y personal de sus egresados.

Este trabajo de investigación tiene como objetivos describir el perfil de los graduados de Licenciatura en Nutrición de la Facultad de Bioquímica y Ciencias Biológicas (FBCB); y la evaluación sobre la formación de grado recibida.

Se realizó una investigación cuali-cuantitativa, de corte transversal, descriptiva e interpretativa. La población de estudio estuvo constituida por profesionales graduados de la Licenciatura en Nutrición de la FBCB-UNL, en el periodo 2010-2013.Se realizó un cuestionario que fue cargado en el programa Goog/e Drive, y la modalidad para contestar on-line e individual.

Respecto al perfil de los graduados existe un predominio del sexo femenino, y provienen del interior de la provincia de Santa Fe. La evaluación de los mismos sobre la formación de grado recibida fue positiva. Además volverían a elegir la carrera de Licenciatura en Nutrición, y se sienten orgullosos de ser egresados de esta casa de estudio.

Palabras clave: Graduados, Licenciatura en Nutrición, Evaluación de la formación recibida.

\footnotetext{
${ }^{1}$ Egresada de la carrera de Licenciatura en Nutrición. Facultad de Bioquímica y Ciencias Biológicas. Universidad Nacional del Litoral. Santa Fe. Argentina. Ciudad Universitaria- Paraje El Pozo. Ruta Nacional 168. CC 242. Santa Fe. Santa Fe. Argentina. Tel: 0342-4575215/16.

e-mail: rpaulini@fbcb.unl.edu.ar

2 Directora de Extensión. Facultad de Bioquímica y Ciencias Biológicas. Universidad Nacional del Litoral. Santa Fe. Argentina.

rosariopaulini@gmail.com
} 


\section{Summary}

This work is based on the recognition that graduates' follow-up studies constitute a strategy of evaluating research of higher education institutions, while allowing investigate the impact of training in the processes of insertion, professional and personal development of its graduates.

This research aims to describe the profile of graduates of the Degree in Nutrition of the FBCB - UNL, and the evaluation of the under graduate education that they received.

A quali- quantitative, transversal, descriptive and interpretive research was conducte. The study population consisted of graduate professionals of the degree in Nutrition (FBCB - UNL), along 2010-2013.A questionnaire for this work was performed. It was loaded into Google Drive, using an online modality for the answers.

Regarding the profile of graduates there is a predominance of females that come from the interior of the province of Santa Fe. The evaluation of them on undergraduate education received was positive. In addition, they would choose again the Degree in Nutrition and feel proud to be graduates of this Faculty.

Keywords: Graduate, Degree in Nutrition, Training Evaluation 